\title{
Multifaceted Roles of Connexin 43 in Stem Cell Niches
}

\author{
Nafiisha Genet ${ }^{1,2} \cdot$ Neha Bhatt $^{1,2} \cdot$ Antonin Bourdieu ${ }^{1,2} \cdot$ Karen K. Hirschi ${ }^{1,2}$ \\ Published online: 15 February 2018 \\ (C) The Author(s) 2018. This article is an open access publication
}

\begin{abstract}
Purpose of Review Considerable progress has been made in the field of stem cell research; nonetheless, the use of stem cells for regenerative medicine therapies, for either endogenous tissue repair or cellular grafts post injury, remains a challenge. To better understand how to maintain stem cell potential in vivo and promote differentiation ex vivo, it is fundamentally important to elucidate the interactions between stem cells and their surrounding partners within their distinct niches.

Recent Findings Among the vast array of proteins depicted as mediators for cell-to-cell interactions, connexin-comprised gap junctions play pivotal roles in the regulation of stem cell fate both in vivo and in vitro.

Summary This review summarizes and illustrates the current knowledge regarding the multifaceted roles of $\mathrm{Cx} 43$, specifically, in various stem cell niches.
\end{abstract}

Keywords Connexin $43 \cdot$ Stem cell niches $\cdot$ Cell-to-cell interactions $\cdot$ Vascular endothelial cells

\section{Introduction}

Cell-to-cell communication is required to coordinate and maintain physiologic cellular activities within tissues. Gap junction (GJ) channels that form between juxtaposed membranes of two adjacent cells connect their cytosols and enable the intercellular transfer of ions, metabolites, soluble factors, and messenger molecules $(<1 \mathrm{kDa})$, which regulate signaling pathways needed for cell survival, proliferation, and fate decisions. This type of intercellular communication is thought to play an important role in stem cell niches to regulate stem and progenitor cell activation and proliferation. However, although the existence of GJ in adult niches, such as in bone marrow, has been known for over 30 years, their function(s) is not clearly defined. In fact, functional studies aimed at understanding the

This article is part of the Topical Collection on Stem Cell Switches and Regulators

Karen K. Hirschi

karen.hirschi@yale.edu

1 Department of Medicine, Genetics and Biomedical Engineering, Yale Cardiovascular Research Center, Vascular Biology Therapeutics Program, New Haven, USA

2 Yale Stem Cell Center Yale University School of Medicine, 300 George St, New Haven, CT 06511, USA role of connexin-comprised GJ in the bone marrow and neural as well as skin stem cell niches are all underway, and we will provide an overview of their common and unique role(s) in the regulation of stem and progenitor cell survival, proliferation, and fate in these distinct microenvironments.

\section{Connexins, Connexons, and Gap Junctions}

Connexins $(\mathrm{Cx})$ are highly conserved proteins both structurally and topologically. They consist of four transmembrane domains (M1, M2, M3, and M4), one intracellular loop (IL), and two extracellular loops (E1 and E2); both the N- and Ctermini are cytoplasmic [1,2] (Fig. 1). Cx proteins are first synthetized in the endoplasmic reticulum and the hexameric oligomerization of six $\mathrm{Cx}$ into a connexon takes place in the trans-Golgi network. The connexon or hemi-channel is then transported to the plasma membrane where it can dock to another hemi-channel of an adjoining cell to form an intercellular, or GJ channel. The docking of two hemi-channels requires the formation of disulfide bonds between three cysteine residues on the extracellular loops E1 and E2 of each $\mathrm{Cx}$ (Fig. 1). Many GJ then assemble together to form GJ plaques [3]. Newly synthetized connexons are incorporated on the outer edges of the junctional plaque, while older GJ simultaneously migrates toward the center of the plaque where they 


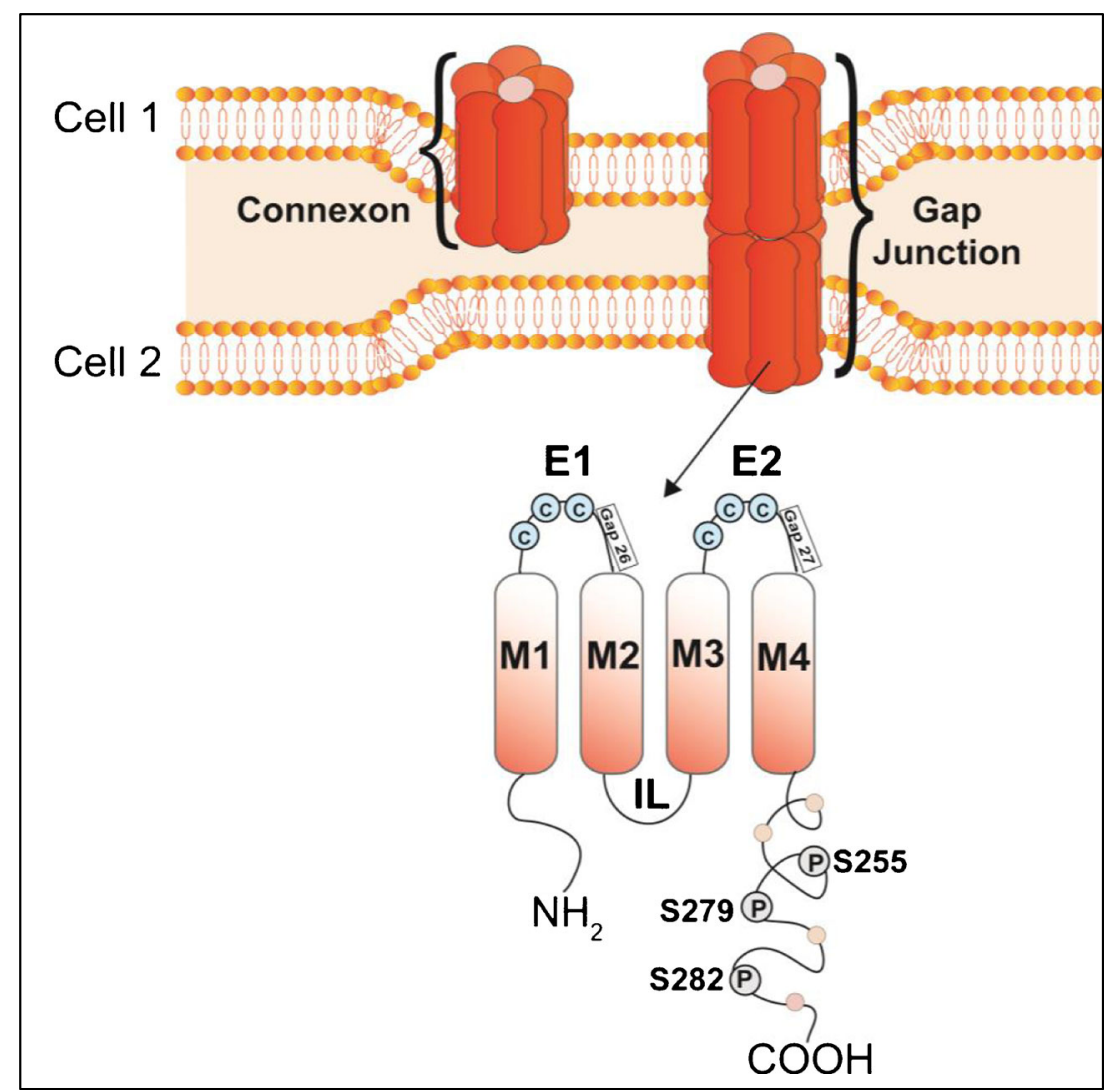

Fig. 1 Structural organization of a connexin $(\mathrm{Cx})$ protein, a connexon hemichannel, and a gap junction. One connexon or hemi-channel is formed by the association of six connexin $(\mathrm{Cx})$ proteins. Two hexameric connexons between two adjoining cells dock to form a gap junction channel. Topologically, one $\mathrm{Cx}$ is composed of four transmembrane domains (M1 to M4), two extracellular loops (E1 and E2), one intracellular loop (IL), and intracellular amino $\left(\mathrm{NH}_{2}\right)$ and carboxy
(COOH)-termini. E1 and E2 have three cysteine residues $(\mathrm{C})$ that form disulfide bonds with adjoining $\mathrm{Cx}$ proteins, allowing the docking of two connexons. The Cx-mimetic blocking peptides Gap26 and Gap27 specifically target E1 and E2, respectively. The C-terminal is subjected to a variety of post-translational modifications, including phosphorylation at the S255, S279, and S282 sites by the mitogen-activated protein kinases (MAPK) are internalized into connexosomes for degradation. Degradation processes involve the proteasome, lysosome, phago-lysosomal, and autophagy pathways [4-8]. GJ channels within plaques have a high turnover rate since $\mathrm{Cx}$ protein half-lives are relatively short, ranging from 1.5 to $5 \mathrm{~h} \mathrm{[9]}$. The modulation of the $\mathrm{Cx}$ turnover rate represents an important mechanism by which cells regulate GJ intercellular coupling (GJIC) [10].

The complex $\mathrm{Cx}$ gene family comprises 21 isoforms in mice and 20 isoforms in humans; 19 of them are orthologous pairs due to their sequence identity. Hemichannels can be formed by identical $\mathrm{Cx}$ isoforms, known as homomeric connexons, or by combination of different $\mathrm{Cx}$ isoforms assembling into heteromeric connexons. The association of two homomeric connexons forms a homotypic GJ, and the docking of either one homomeric with one heteromeric connexon or two heteromeric connexons forms heterotypic GJ channels. [11]. In this review, we will focus only on $\mathrm{Cx} 43$, as it is the most highly expressed in stem cell niches and the best characterized Cx protein.

\section{Channel-Dependent and Channel-Independent Functions of Cx}

Channel-Dependent Functions The formation of intercellular GJ channels is highly dependent on the bonding of cysteine residues in the extracellular loops of $\mathrm{Cx}$ proteins in juxtaposed hemi-channels. The hydrophilic pore of GJ channels is formed by the third transmembrane domain (M3) due to its high content in negatively and positively charged residues [12]. GJIC is highly regulated by the number of GJ channels present within the cellular membranes, their functional state (open vs. closed), and selectivity of molecules that traverse the channels. The functionality of GJ channels is dependent on the phosphorylation state of the $\mathrm{Cx}$ proteins that comprise the channels, and various other factors such as $\mathrm{Ca}^{2+}, \mathrm{O}_{2}$, shear 
stretch, $\mathrm{pH}$, voltage, and protein to protein interactions [13]. Several tools have been developed to study GJIC, or channeldependent function of $\mathrm{Cx}$. They include drugs that close GJ channels, such as heptanol, octanol, $18 \alpha$-glycyrrhetinic acid, carbenoxolone, and oleamide; however, these reagents are non-specific pharmacological inhibitors [14-16]. More GJselective regulation can be mediated via synthetic $\mathrm{CX}$ mimetic blocking peptides, such as Gap26 and Gap27, which are homologous to specific amino acid sequences in the EC loops E1 and E2, respectively [17-20] (Fig. 1). Genetic approaches using single site mutations of specific amino acids in the $\mathrm{Cx}$ sequence are alternate and robust tools to study GJ channel function. In addition, the threonine $(\mathrm{T})$ residue located at the cytoplasmic end of M3 is conserved among the $\mathrm{Cx}$ proteins; mutating the $\mathrm{T}$ residue into an alanine (A) results in a "closed channel" state. For example, generating the Cx43T154A mutation in Cx43 renders its channels non-functional, despite the fact that channels retain their capacity to localize properly within the plasma membrane and form GJ plaques [21].

As mentioned earlier, the $\mathrm{Cx}$ gene family is highly conserved; however, the length and sequence of the cytosolic Cterminus or carboxy tail (CT) are different from one $\mathrm{Cx}$ to another. The $\mathrm{CT}$ provides sites for protein to protein interactions and is subjected to extensive post-translational modifications that regulate $\mathrm{Cx}$ intracellular trafficking and GJ channel gating [22]. Post-translational modifications include acetylation, $S$-nitrosylation, ubiquitination, SUMOylation, and phosphorylation. Phosphorylation of the $\mathrm{Cx} 43 \mathrm{CT}$ tail controls GJIC through GJ channel gating, Cx trafficking, assembly of connexons into GJ, GJ endocytosis, and degradation [22]. Cx phosphorylation is often triggered in response to the activation of receptor protein tyrosine kinases. $\mathrm{Cx} 43$ is mainly phosphorylated on serine (S) residues but can also be phosphorylated on tyrosine and threonine residues. Some sites when phosphorylated enhance GJIC (activating phosphosites), while others can inhibit GJIC (inhibitory phosphosites). For example, epidermal growth factor (EGF) inhibits GJIC by activating MAPK-dependent phosphorylation of $\mathrm{Cx} 43$ at S255, 279, and 282 [23-26]. Platelet-derived growth factor (PDGF) inhibits GJIC via MAPK and PKC signaling cascades. Additionally, PDGF and EGF can induce the endocytosis and degradation of $\mathrm{Cx} 43$ [27-30]. Proteins enhancing GJIC include casein kinase (CK1) and cAMP. CK1 promotes GJ assembly by initial phosphorylation of $\mathrm{Cx} 43$ at $\mathrm{S} 325,328$, and 330 followed by S306 or 314 in a hierarchical fashion [31]. Elevated cytoplasmic levels of cAMP enhance GJIC via protein kinase $\mathrm{A}(\mathrm{PKA})$ and increase trafficking of $\mathrm{Cx} 43$ to the plasma membrane and GJ assembly [32-34].

Channel-Independent Functions There is increasing evidence that the $\mathrm{Cx} 43 \mathrm{CT}$ interacts with other proteins to modulate intracellular signaling, thus allowing $\mathrm{Cx} 43$ to regulate cell proliferation, differentiation, and migration, independent of its ability to form functional intercellular GJ channels. Cancer researchers have highlighted the importance of the $\mathrm{Cx} 43 \mathrm{CT}$ in the regulation of tumor cell growth, independent of GJ formation [35-38]. For example, Huang and coworkers transfected $\mathrm{Cx} 43 \mathrm{CT}$ into glioma cells, which suppressed tumor growth, without establishing GJIC [39]. In addition, enforced expression of the $\mathrm{Cx} 43 \mathrm{CT}$ in mouse neuroblastoma cells was sufficient to induce growth arrest to the same extent as the full-length, wild-type (WT) $\mathrm{Cx} 43$ [36]. Finally, stable overexpression of the Cx43 CT in HeLa cells significantly decreased proliferation; in these cells, the $\mathrm{CT}$ fragment was localized to the cytoplasm and the nucleus, providing further evidence that plasma membrane localization and channel formation are not required for $\mathrm{CX}$-mediated growth control [40].

Regarding mechanism(s) of action, the $\mathrm{Cx} 43 \mathrm{CT}$ promotes the degradation of the S-phase kinase-associated protein 2 (Skp2), which, in turn, upregulates p27 and subsequently arrests cell growth [41]. Moreover, the Cx43 $\mathrm{CT}$ also upregulates the expression of $\mathrm{p} 53$, a potent tumor suppressor $[42,43 \cdot \bullet]$. The $\mathrm{Cx} 43 \mathrm{CT}$ also functions as a signaling hub/interactome, and $\beta$-catenin is among the interacting partners involved in its GJIC-independent function. Interaction of the $\mathrm{Cx} 43 \mathrm{CT}$ with $\beta$-catenin suppresses downstream Wnt-mediated regulation of proliferation, migration, and apoptosis $[44,45]$. The $\mathrm{CT}$ of $\mathrm{Cx} 43$ also interacts with zonula occludens (ZO)-1 and ZO-2 at their PDZ-binding motifs, as well as $\alpha$ and $\beta$ tubulin, the main components of microtubules [46].

The use of genetically malleable mouse models has also shed light on the in vivo role of the Cx43 CT. For example, mice carrying the mutation $\mathrm{Cx} 43 \mathrm{~K} 258$ stop, in which the last 125 amino acid residues of the CT have been deleted, die shortly after birth due to defective epidermal barrier, associated with impaired terminal differentiation of keratinocytes. Haplo-insufficient K258stop/Cx43KO mice, carrying one K258stop and one Cx43 KO allele, make functional GJ despite the absence of any full-length $\mathrm{Cx} 43$, but the truncation of the $\mathrm{CT}$ affects the localization of $\mathrm{Cx} 43$ and reduces the number of junctional plaques in vivo [47]. These mice also have altered neuronal migration in the neocortex, comparable to that observed in $\mathrm{Cx} 43 \mathrm{KO}$ mice [48]. The CT has also been shown to be an important mediator of neuroprotection during cerebral ischemia by enhancing astrogliosis after stroke [49]. More recently, the Cx43 CT has been shown to bind to multiple signaling proteins needed for optimal osteoblast function, namely $\mathrm{PKC} \delta$, ERK, and $\beta$ catenin $\left[50^{\bullet \bullet}\right]$. As a result, the $\mathrm{K} 258$ stop/Cx43KO mice have several defects in osteoblast proliferation, differentiation, and collagen deposition [51•]. This clearly emphasizes the importance of the $\mathrm{Cx} 43 \mathrm{CT}$, possibly as a docking hub for multiple proteins needed for different signaling cascades regulating cell function, and this may be relevant to $\mathrm{Cx} 43$ regulation of stem and progenitor cells. 


\section{Cx43 in Stem Cell Niches}

Definition of Adult Stem Cell Niches The concept of a specialized microenvironment, or niche, for stem cells was first proposed by Schofield more than 3 decades ago [52]. At that time, he suggested that niches have a distinct anatomical location within tissues and that removal of stem cells from their niches induces differentiation. Since then, mammalian stem cell niches have been described in multiple organ systems and shown to provide structural support and molecular cues that determine stem cell quiescence, self-renewal, and activation. Therefore, the niche is not only a physical location for stem cells, but a hub where various extrinsic signals are integrated to regulate intrinsic stem cell behavior. These cues include cell-to-cell contacts, cell-to-matrix interactions, and autocrine and paracrine-soluble effectors. In this second part of the review, we will focus on the role of indirect and direct cellular interactions among niche cells in various stem cell niches and, more specifically, on interactions mediated via Cx43-hemi-channels and Cx43-containing GJ channels.

Hematopoietic Stem Cell Niche: Bone Marrow Adult hematopoietic stem cells (HSC) reside in the bone marrow, where they constantly self-renew, proliferate, and differentiate to enable the production of mature blood cell types throughout life. The critical cellular components of the bone marrow hematopoietic niche are still under debate and intense investigation. At present, the field suggests two types of niches: (1) the osteoblastic niche and (2) the vascular niche $[53,54 \bullet \bullet]$ (depicted in Fig. 2). It is likely that quiescent $\mathrm{HSC}$ reside in the osteoblastic niche, which is located along the peripheral bone endosteal region [55-57]. In the centrally localized vascular niche, thought to favor differentiation, HSC lie in close proximity to sinusoidal blood vessels, arterioles, and perivascular cells [55-65]. Similarly, the endosteal region is equally vascularized, which implicates vascular endothelial cells as potential regulators of HSC behavior in both the osteoblastic and vascular niches.

Several studies have delineated the roles of cell-to-cell interactions between HSC and surrounding endothelial cells, stromal cells, and osteoblasts in the regulation of adult HSC "stemness" capacity. In the osteoblastic niche, HSC and osteoblasts interact via Wnt- $\beta$ catenin signaling and Notch signaling to maintain HSC [53, 66-75]. In addition, the existence of functional GJ has also been reported in the bone marrow niche, wherein $\mathrm{Cx} 43$ is the most highly expressed $\mathrm{Cx}$ [76-80]. Several groups have studied the role of Cx43mediated interactions between bone marrow stromal cells and osteoblasts in the regulation of HSC. For example, Wagner and coworkers identified $\mathrm{Cx} 43$ as an important regulator of HSC self-renewal [81]. In bone marrow stromal cells, Cx43 also exists within hemi-channels that are not docked with adjacent cells and trigger the release of ATP, activating purinergic receptors, which upon activation increases HSC growth and potential [80]. Several in vitro studies reported that bone marrow stromal cells expressing Cx43 regulate hematopoiesis. In the S17 stromal cell line co-cultured with HSC, overexpression of $\mathrm{Cx} 43$ delays differentiation of blood cells, while loss of $\mathrm{Cx} 43$ accelerates myelopoiesis [82].

The vascular niche harbors sinusoidal blood vessels and arterioles that control HSC maintenance. It has been shown that sinusoidal endothelial cells support HSC quiescence and self-renewal through the paracrine secretion of the growth factor pleitrophin (PTN) and the angiocrine factor Jagged1
Fig. 2 Cellular architecture of the hematopoietic stem cell (HSC) niche in the adult bone marrow. The osteoblastic niche resides along the endosteum, located at the periphery of the bone, while the vascular niche is centrally localized in the bone marrow. HSC are localized adjacent to sinusoids and arterioles. The central vascular niche is thought to favor activation and differentiation of HSC. Cx43comprised gap junctions between osteoblasts regulate HSC behavior within the niche. Although vascular endothelial cells and HSC express Cx43, the existence, and physiologic role, of Cx43-mediated interactions between vascular endothelial cells and $\mathrm{HSC}$ remains to be determined

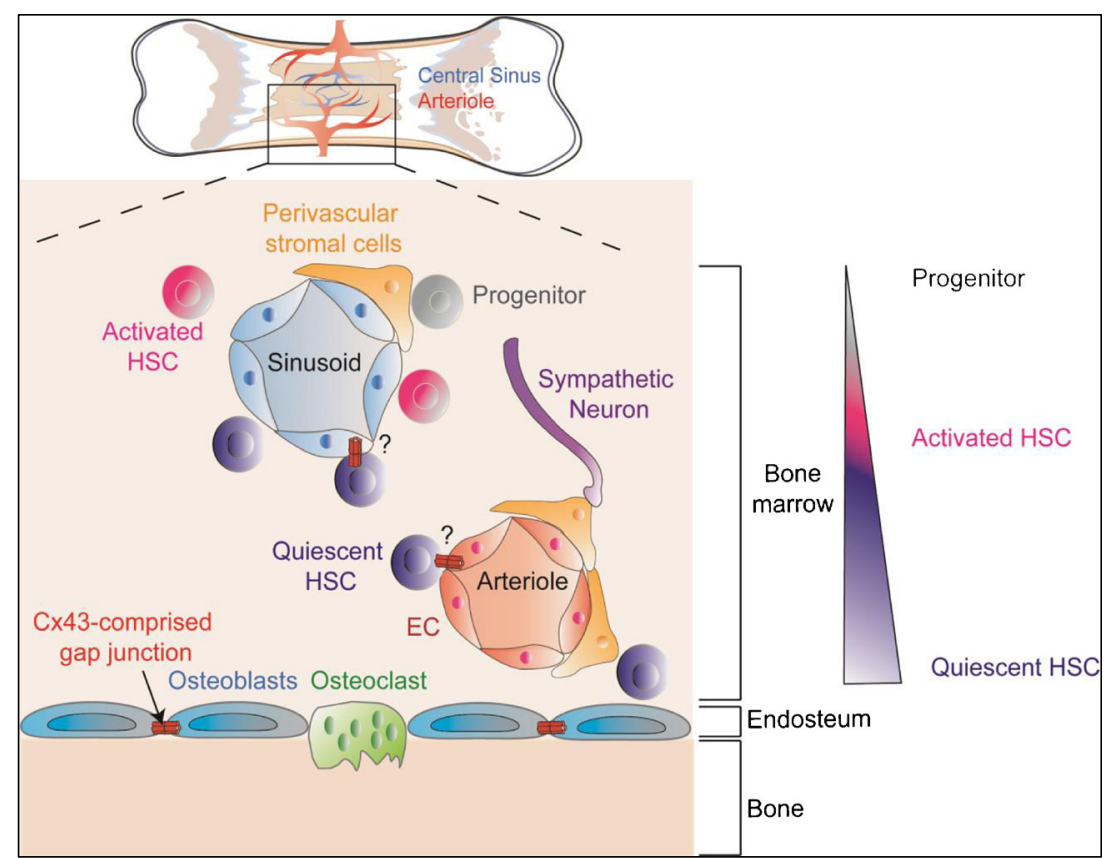


$[83,84]$. Conversely, direct contact between endothelial cells and HSC via endothelial-expressed E-selectin promotes HSC proliferation [85]. In the arteriolar niche, perivascular cells expressing the chondroitin sulfate proteoglycan neural/glial antigen NG2 maintains HSC quiescence and reduces the long-term repopulating capacity of HSC [65].

Although Cx43-deficient $\left(\mathrm{Cx} 43^{-1}\right)$ mice die shortly after birth due to heart malformations [86], precluding postnatal hematopoietic studies, embryonic $\mathrm{Cx} 43^{-/-}$mice exhibit reduced fetal liver HSC and progenitor cells. Cx43 deficiency in stromal cells, specifically, results in a reduction of functional HSC and progenitor cells in the fetal liver and impairs the growth and differentiation of bone marrow HSC, suggesting that $\mathrm{Cx} 43$ acts as critical regulator of hematopoiesis [87, 88]. Furthermore, $\mathrm{Cx} 43$ was shown to be critical for injuryinduced hematopoietic regeneration in adults [89]. Cx43 is thought to prevent irradiation-induced mitochondrial superoxide anion $\left(\mathrm{O}_{2}{ }^{\prime}\right)$ accumulation in the HSC [90]; hence, $\mathrm{Cx} 43$ protects $\mathrm{HSC}$ and progenitor cells from $\mathrm{O}_{2}$-induced senescence, allowing them to replace lost HSC following injury [91, 92]. Whether Cx43-mediated contacts between HSC and vascular endothelial cells in the bone marrow niche are critical for HSC regulation remains unknown, opening new avenues for investigation.

Neural Stem Cell Niches Neural stem cells (NSC) and progenitor cells reside in two neurogenic regions of the adult mammalian brain: the subventricular zone (SVZ) lining the walls of the lateral ventricles (depicted in Fig. 3) and the subgranular zone (SGZ) of the dentate gyrus (DG) in the hippocampus. Within these two neurogenic niches, NSC display selfrenewal capacity, and the ability to differentiate into glial (astrocytes and oligodendrocytes) and neuronal (granular and periglomerular neurons) lineages. These brain regions support ongoing neurogenesis throughout development and postnatally.

Subventricular Zone In the SVZ, NSC reside in the subependymal region, separated from the cerebral spinal fluid (CSF)-filled ventricles by a layer of ciliated ependymal cells (also called Type-E cells). The SVZ functions as a neurogenic environment maintaining NSC in a poised and undifferentiated state, ready to react to changes in the microenvironment. Within the niche, quiescent or slow-proliferating radial-gliallike NSC (also called Type-B cells) are "anchored" by two distinct cell types [93]. On the ventricular side, they are attached to ependymal cells and protrude apical processes through the ependymal cell layer, into CSF; on the parenchymal side, they project specialized basal-end feet toward endothelial cells of blood vessels [94-97]. The apical processes arising from a Type-B cells are surrounded by rosette-like structures formed by two types of ependymal cells: multiciliated Type-E1 cells controlling CSF flow and Type-E2 cells

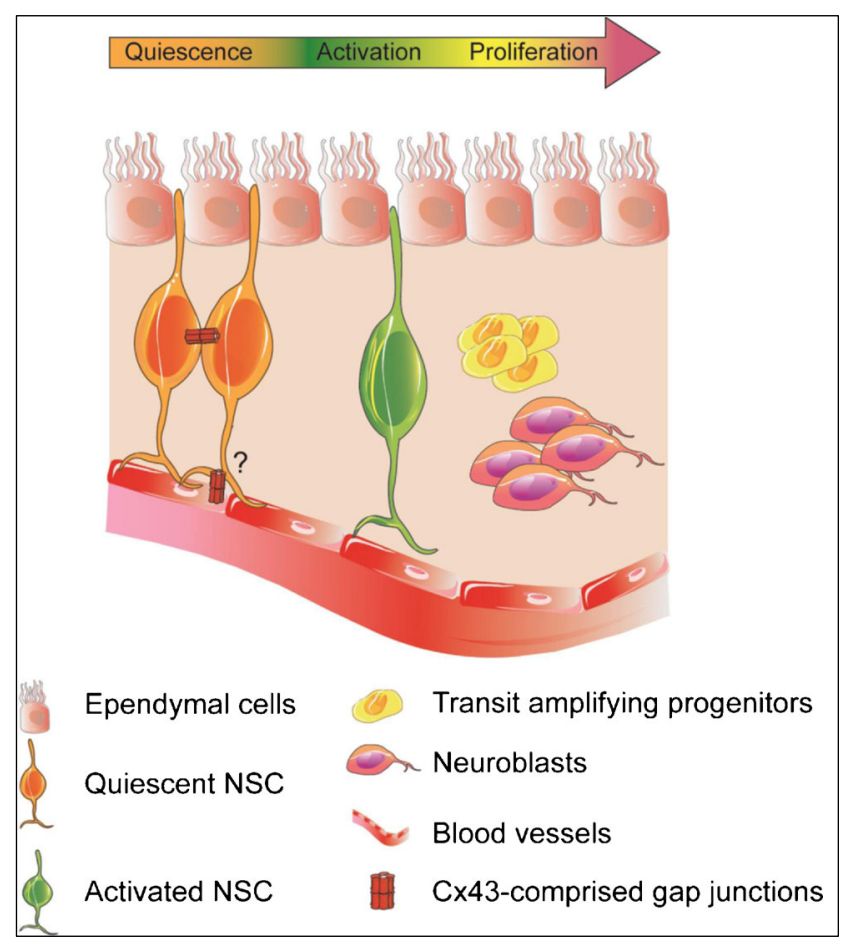

Fig. 3 Cellular architecture of the adult brain subventricular zone (SVZ) niche. The SVZ is a polarized niche with a network of quiescent and activated neural stem cells (NSC) extending basal end-feet on endothelial cells of blood vessels, while protruding apical processes through the layer of ependymal cells that line the lateral ventricles. When neurogenesis is initiated in the SVZ, activated NSC rapidly divide into transit-amplifying progenitors that give rise to neuroblasts. It is thought that $\mathrm{Cx} 43-$ containing gap junctions among quiescent NSC regulate NSC behavior. Whether $\mathrm{Cx} 43$ - and gap junction-mediated interactions between NSC and endothelial cells, or ependymal cells, exist and contribute to NSC regulation remains to be determined

composed of two cilia and complex basal bodies. Together, quiescent Type-B cells and ependymal cells form pinwheel structures [96].

The process of neurogenesis is initiated in the SVZ when Type-B cells are activated and become fast dividing progenitors, named transit-amplifying, or Type-C, cells. Type-C cells then form small clusters and differentiate into migrating neuroblasts, called Type-A cells [98]. Type-A cells continue to proliferate but ten times slower than Type-C cells $[93,99]$. Type-A neuroblasts migrate from the anterior part of the SVZ along the rostral migratory stream toward the olfactory bulb and eventually differentiate into granular and periglomerular neurons [100-102].

In the SVZ, the blood-brain barrier is "leaky," with vascular endothelial cells lacking astrocyte end-feet and pericytes coverage, thus enabling direct interactions between NSC and endothelial cells via adhesion molecules, tight junctions, and GJ, which are thought to regulate NSC self-renewal and potential [103-111]. The SVZ microvasculature is thought to be an integral component of the NSC niche and is suggested to support NSC self-renewal, maintenance, proliferation, as well 
as differentiation and migration of neural progenitor cells [95-97]. Cx43 is highly expressed by NSC and vascular endothelial cells in the SVZ, and although the role of GJIC between these cell types is unclear, it is known that $\mathrm{Cx} 43$ plays key roles in (1) maintaining neural progenitor cells in nondifferentiated and proliferative states [112, 113], (2) promoting neuroblast migration $[114,115]$, and (3) maintaining the cellular architecture of the SVZ niche [116]. It was demonstrated that $\mathrm{Cx} 43$ channel activity stimulates neural progenitor cell proliferation by synchronizing $\mathrm{Ca}^{2+}$ activity and regulating intracellular $\mathrm{Ca}^{2+}$ homeostasis $[117,118]$. In early postnatal SVZ, cell cycle progression of NSC requires an increase in blood flow in the niche, which is under the control of neurometabolic vascular coupling provided by ATP release from neural progenitor cells $[119,120]$. Cx43 hemi-channel activity might contribute to the mechanisms required for adequate blood flow to regions of extensive cell proliferation through the release of vasoactive substances triggering the local hemodynamic responses [80].

Subgranular Zone of the Dentate Gyrus Within the DG of the hippocampus, NSC reside in the subgranular zone (SGZ) between the granule layer and the hilus. In the DG, Type-B radial glia-like cells are thought to represent the NSC population that can generate proliferating intermediate progenitor cells (TypeD cells) with transit-amplifying characteristics [102]. These Type-D cells progressively generate more differentiated progeny and migrate a short distance to the granule layer, where they differentiate into mature granule neurons (Type-G cells) and integrate the hippocampal circuits [107, 121, 122]. Type$\mathrm{B}$ cells have basal processes that contact blood vessels beneath the DG, as well as apical processes that contact the granule layer, and there is a close relationship between proliferating neural progenitors and endothelial cells in the hippocampus [123]. In the SGZ, neurogenesis is coupled to angiogenesis, as suggested by high levels of vascular endothelial growth factor (VEGF) and vascular endothelial growth factor receptor 2 (VEGFR2) [124]. More recently, it has been demonstrated that VEGFR3 controls NSC activation in hippocampal neurogenesis, and VEGFR3::YFP mice demonstrates VEGFR3 expression in NSC [125•].

In addition to VEGF signaling, there is growing evidence implicating cell-to-cell interactions mediated by $\mathrm{Cx} 43$ containing GJ in hippocampal neurogenesis. In the postnatal hippocampus, neural progenitors are strongly coupled by GJ comprised of $\mathrm{Cx} 43$ [126, 127], and deletion of $\mathrm{Cx} 43$ in vivo affects hippocampal neurogenesis [128]. This observation was further confirmed by Liebman and coworkers, who demonstrated that $\mathrm{Cx} 43$ promotes the survival of newborn neurons [129]. $\mathrm{Cx} 43$ has also been shown to be upregulated in the DG following traumatic brain injury, enhancing postinjury neurogenic response [130••]. Single-cell RNA-seq and bioinformatic approaches demonstrated reduced cell-to-cell communications as quiescent NSC progress toward an activated cycling state; tight junction protein $2(\mathrm{ZO}-2)$ and GJA1 (Cx43) were among the downregulated genes [131••]. It is possible that during this process, $\mathrm{Cx} 43$ is not forming GJ channels but is required to stabilize other junctional proteins, via the CT. The expression of $\mathrm{Cx} 43$ in vascular endothelial cells in the DG has not been reported, and whether the vasculature influences hippocampal neurogenesis through $\mathrm{Cx} 43$ containing GJ remains to be investigated.

Skin Stem Cell Niche The skin is a complex organ harboring distinct populations of stem cells and is layered with epidermis, dermis, and subcutaneous fat, the dermis being the outermost layer. Stem cell populations within the skin include epidermal, hair follicle, and melanocyte stem cells [132]. In adult skin, hair follicles undergo repeated cycles of apoptosis (catagen) and regeneration (anagen) followed by a rest period (telogen) [132-134]. Slow-cycling hair follicle stem cells (HFSC) reside in a specialized "bulge" pocket, located at the top of the follicle that does not degenerate throughout the catagen phase of the hair cycle. HFSC are subdivided into two populations, quiescent stem cells located in the bulge (Bu-SC) and primed stem cells located beneath the bulge within the hair germ, which are more prone to proliferation. During the anagen phase, hair germ develops into a matrix of fast-cycling transit-amplifying progenitors followed by a terminal differentiation forming the hair shaft. In contrast, $\mathrm{Bu}-\mathrm{SC}$ give rise to a population of cells that retains stem cell properties. The unique behavior of slow- and fastcycling HFSC is suggested to depend on differential exposure to quiescent and activating niche cues. Given their isolated localization in the bulge pocket, Bu-SC are exposed only to quiescent-maintaining signals through autocrine, as well as paracrine, signaling from nearby blood vessels and neurons. After the first round of hair generation, differentiated transit-amplifying cells also provide cues to maintain quiescence among Bu-SC $[135,136]$. Capillary networks are present in the region above the bulge, and these plexi might influence hair cycling. Interestingly, when angiogenesis is inhibited, anagen induction is delayed, suggesting that angiogenic factors might regulate HFSC activity through vascular-HFSC interactions [137].

Cx43 is the most highly expressed Cx protein in the skin, predominantly in melanocytes, dermal papillae, and keratinocytes, and is involved in the process of HFSC renewal, regeneration, and wound healing [138]. In early mouse development, $\mathrm{Cx} 43$ was found in all of the stratified layers of the epidermis. Cx43 is also implicated in maintaining undifferentiated, multipotent skin stem cells. Compared to WT mice, HFSC of newborn $\mathrm{Cx} 43^{-/-}$mice exhibit less migration, coupling, and potential, suggesting that $\mathrm{Cx} 43$ plays an 
important role in maintaining undifferentiated and multipotent stem cell niche in the skin [139].

In the hair follicle, adhesion molecules were shown to play an important role in epidermal and hair follicle development and maintenance. E-cadherin ablation in adult epidermis leads to a severe differentiation defect and to decreased proliferation of hair follicle progenitor cells [140]. In addition, in mouse epidermal cells, E-cadherin regulates GJIC via posttranslational regulation of $\mathrm{Cx} 43$, suggesting that $\mathrm{Cx} 43$ and E-cadherin act synergistically for hair follicle maintenance [141, 142].

In acute normal skin injury, $\mathrm{Cx} 43$ mRNA level and protein expression are reduced during the entire wound-healing process and this reduction is associated with ECM remodeling, proliferation, and migration of keratinocytes and fibroblast, and regulation of inflammatory responses through cytokines, chemokines, and growth factors [143, 144, 145•]. Although downregulation of $\mathrm{Cx} 43$ has been proposed as the main mechanism accelerating the process of acute wound healing [146-148], this dogma has been challenged. Ghatnekar and coworkers showed that $\mathrm{Cx} 43$ protein levels are unchanged during acute wound healing [149]. These authors argued that the loss Cx43 CT disrupts the interaction between ZO-1 and $\mathrm{Cx} 43$. This leads to a shift of connexon distribution from nonjunctional pools to association in GJ, which increases GJ size, whereas the number is reduced [150]. Conversely, in chronic injury, such as ulcers, $\mathrm{Cx} 43$ expression is increased near the border of the wound $[148,151]$.

\section{Summary and Conclusions}

Based on the ubiquity of its expression and the multiple modes of action (GJ and non-GJ), Cx43 is a crucial regulator of stem cell behavior in their respective niches. In this review, we have discussed the known multifaceted roles of $\mathrm{Cx} 43$ during development, as well as during adult tissue homeostasis and injuryinduced regeneration in different stem cell niches. The synergistic interaction of $\mathrm{Cx} 43$ with other junctional and cytoskeleton proteins indicates that beside its junctional role, as either a channel or a hemi-channel, $\mathrm{Cx} 43$ also functions as a complex stabilizer at adhesion sites in the regulation of stem cell behavior. It is more and more accepted that most of the unique features, interaction sites, and regulatory domains of $\mathrm{Cx} 43$ are attributed to its CT. Thus, it is important to further explore the role of $\mathrm{Cx} 43 \mathrm{CT}$ in the regulation of stem cell behavior and niche maintenance.

We have also highlighted that adult HSC and NSC lie in a vascular niche and that stem cells in other niches may also be regulated by surrounding vasculature. It is important to continue investigating how the close contact of stem cells with the vasculature regulates stem cell behavior. Although we have a substantial amount of data pertaining to the contribution of
Cx43 in the maintenance of stem cell niches starting from embryonic development to normal tissue homeostasis and post-injury regeneration in adults, most of these studies remain predominantly descriptive. We still have a long way to go to completely understand the mechanisms by which $\mathrm{Cx} 43$ regulates stem cells.

The lethality of $\mathrm{Cx} 43^{---}$mice at birth makes it complex and challenging to study the role of $\mathrm{Cx} 43$ post-natally. However, several conditional $\mathrm{KO}$ mouse models have been developed in an attempt to address the role of $\mathrm{Cx} 43$ in the regulation of stem cell niches in both physiological and pathophysiological conditions. These models have also provided information enabling the optimization of in vitro systems to study and manipulate the precise role of $\mathrm{Cx} 43$, which might ultimately be useful in clinical applications. In the stem cell field, we are all working toward the development of regenerative therapies to repair injury and delay the effects of aging. Understanding the functional roles and the mechanisms of action of $\mathrm{Cx} 43$ in bone, neural and skin stem cell niches will provide insights needed for regenerative medicine.

Acknowledgements Our work is supported by NIH grants HL128064, EB016629, and EB017103, as well as CT Innovations grants 15-RMBYALE-04 and 15-RMB-YALE-07 to KKH

\section{Compliance with Ethical Standards}

Conflict of Interest Nafiisha Genet, Neha Bhatt, Antonin Bourdieu, and Karen K. Hirschi declare that they have no conflict of interest.

Human and Animal Rights and Informed Consent This article does not contain any studies with human or animal subjects performed by any of the authors.

Open Access This article is distributed under the terms of the Creative Commons Attribution 4.0 International License (http:// creativecommons.org/licenses/by/4.0/), which permits unrestricted use, distribution, and reproduction in any medium, provided you give appropriate credit to the original author(s) and the source, provide a link to the Creative Commons license, and indicate if changes were made.

\section{References}

Papers of particular interest, published recently, have been highlighted as:

- Of importance

•- Of major importance

1. Goodenough DA, Paul DL. Beyond the gap: functions of unpaired connexon channels. Nat Rev Mol Cell Biol. 2003;4(4):285-94. https://doi.org/10.1038/nrm1072.

2. Goodenough DA, Paul DL. Gap junctions. Cold Spring Harb Perspect Biol. 2009;1(1):a002576. https://doi.org/10.1101/ cshperspect.a002576. 
3. Gaietta G, Deerinck TJ, Adams SR, Bouwer J, Tour O, Laird DW, et al. Multicolor and electron microscopic imaging of connexin trafficking. Science. 2002;296(5567):503-7. https://doi.org/10. 1126/science.1068793.

4. Falk MM, Baker SM, Gumpert AM, Segretain D, Buckheit RW 3rd. Gap junction turnover is achieved by the internalization of small endocytic double-membrane vesicles. Mol Biol Cell. 2009;20(14):3342-52. https://doi.org/10.1091/mbc.E09-04-0288.

5. Falk MM, Kells RM, Berthoud VM. Degradation of connexins and gap junctions. FEBS Lett. 2014;588(8):1221-9. https://doi. org/10.1016/j.febslet.2014.01.031.

6. Laird DW. Life cycle of connexins in health and disease. Biochem J. 2006;394(Pt 3):527-43. https://doi.org/10.1042/BJ20051922.

7. $\mathrm{Su} \mathrm{V}$, Cochrane K, Lau AF. Degradation of connexins through the proteasomal, endolysosomal and phagolysosomal pathways. J Membr Biol. 2012;245(7):389-400. https://doi.org/10.1007/ s00232-012-9461-3.

8. Su V, Lau AF. Connexins: mechanisms regulating protein levels and intercellular communication. FEBS Lett. 2014;588(8):121220. https://doi.org/10.1016/j.febslet.2014.01.013.

9. Berthoud VM, Minogue PJ, Laing JG, Beyer EC. Pathways for degradation of connexins and gap junctions. Cardiovasc Res. 2004;62(2):256-67. https://doi.org/10.1016/j.cardiores.2003.12. 021.

10. Herve JC, Derangeon M, Bahbouhi B, Mesnil M, Sarrouilhe D. The connexin turnover, an important modulating factor of the level of cell-to-cell junctional communication: comparison with other integral membrane proteins. J Membr Biol. 2007;217(1-3):21-33. https://doi.org/10.1007/s00232-007-9054-8.

11. Cottrell GT, Burt JM. Functional consequences of heterogeneous gap junction channel formation and its influence in health and disease. Biochim Biophys Acta. 2005;1711(2):126-41. https:// doi.org/10.1016/j.bbamem.2004.11.013.

12. Bennett MV, Barrio LC, Bargiello TA, Spray DC, Hertzberg E, Saez JC. Gap junctions: new tools, new answers, new questions. Neuron. 1991;6(3):305-20. https://doi.org/10.1016/08966273(91)90241-Q.

13. Freund-Michel V, Muller B, Marthan R, Savineau JP, Guibert C. Expression and role of connexin-based gap junctions in pulmonary inflammatory diseases. Pharmacol Ther. 2016;164:105-19. https://doi.org/10.1016/j.pharmthera.2016.04.004.

14. Guan X, Cravatt BF, Ehring GR, Hall JE, Boger DL, Lerner RA, et al. The sleep-inducing lipid oleamide deconvolutes gap junction communication and calcium wave transmission in glial cells. J Cell Biol. 1997;139(7):1785-92. https://doi.org/10.1083/jcb.139. 7.1785 .

15. Guo Y, Martinez-Williams C, Gilbert KA, Rannels DE. Inhibition of gap junction communication in alveolar epithelial cells by 18alpha-glycyrrhetinic acid. Am J Phys. 1999;276(6 Pt 1): L1018-26.

16. Takens-Kwak BR, Jongsma HJ, Rook MB, Van Ginneken AC. Mechanism of heptanol-induced uncoupling of cardiac gap junctions: a perforated patch-clamp study. Am J Phys. 1992;262(6 Pt 1):C1531-8. https://doi.org/10.1152/ajpcell.1992.262.6.C1531.

17. Billaud M, Dahan D, Marthan R, Savineau JP, Guibert C. Role of the gap junctions in the contractile response to agonists in pulmonary artery from two rat models of pulmonary hypertension. Respir Res. 2011;12(1):30. https://doi.org/10.1186/1465-992112-30.

18. Billaud M, Marthan R, Savineau JP, Guibert C. Vascular smooth muscle modulates endothelial control of vasoreactivity via reactive oxygen species production through myoendothelial communications. PLoS One. 2009;4(7):e6432. https://doi.org/10.1371/ journal.pone.0006432.

19. Chaytor AT, Evans WH, Griffith TM. Peptides homologous to extracellular loop motifs of connexin 43 reversibly abolish rhythmic contractile activity in rabbit arteries. J Physiol. 1997;503(Pt 1):99-110. https://doi.org/10.1111/j.1469-7793. 1997.099bi.x.

20. Evans WH, Leybaert L. Mimetic peptides as blockers of connexin channel-facilitated intercellular communication. Cell Commun Adhes. 2007;14(6):265-73. https://doi.org/10.1080/ 15419060801891034 .

21. Beahm DL, Oshima A, Gaietta GM, Hand GM, Smock AE, Zucker SN, et al. Mutation of a conserved threonine in the third transmembrane helix of alpha- and beta-connexins creates a dominant-negative closed gap junction channel. J Biol Chem. 2006;281(12):7994-8009. https://doi.org/10.1074/jbc. M506533200.

22. Solan JL, Lampe PD. Connexin 43 phosphorylation: structural changes and biological effects. Biochem J. 2009;419(2):261-72. https://doi.org/10.1042/BJ20082319.

23. Kanemitsu MY, Lau AF. Epidermal growth factor stimulates the disruption of gap junctional communication and connexin 43 phosphorylation independent of 12-0-tetradecanoylphorbol 13-acetate-sensitive protein kinase $\mathrm{C}$ : the possible involvement of mitogen-activated protein kinase. Mol Biol Cell. 1993;4(8):83748. https://doi.org/10.1091/mbc.4.8.837.

24. Lau AF, Kanemitsu MY, Kurata WE, Danesh S, Boynton AL. Epidermal growth factor disrupts gap-junctional communication and induces phosphorylation of connexin 43 on serine. Mol Biol Cell. 1992;3(8):865-74. https://doi.org/10.1091/mbc.3.8.865.

25. Warn-Cramer BJ, Cottrell GT, Burt JM, Lau AF. Regulation of connexin-43 gap junctional intercellular communication by mitogen-activated protein kinase. J Biol Chem. 1998;273(15): 9188-96. https://doi.org/10.1074/jbc.273.15.9188.

26. Warn-Cramer BJ, Lampe PD, Kurata WE, Kanemitsu MY, Loo LW, Eckhart W, et al. Characterization of the mitogen-activated protein kinase phosphorylation sites on the connexin-43 gap junction protein. J Biol Chem. 1996;271(7):3779-86. https://doi.org/ 10.1074/jbc.271.7.3779.

27. Hossain MZ, Ao P, Boynton AL. Rapid disruption of gap junctional communication and phosphorylation of connexin 43 by platelet-derived growth factor in T51B rat liver epithelial cells expressing platelet-derived growth factor receptor. J Cell Physiol. 1998;174(1):66-77. https://doi.org/10.1002/(SICI)10974652(199801)174:1<66::AID-JCP8>3.0.CO;2-E.

28. Hossain MZ, Jagdale AB, Ao P, Boynton AL. Mitogen-activated protein kinase and phosphorylation of connexin 43 are not sufficient for the disruption of gap junctional communication by platelet-derived growth factor and tetradecanoylphorbol acetate. J Cell Physiol. 1999;179(1):87-96. https://doi.org/10.1002/ (SICI)1097-4652(199904)179:1<87::AID-JCP11>3.0.CO;2-K.

29. Hossain MZ, Jagdale AB, Ao P, Kazlauskas A, Boynton AL. Disruption of gap junctional communication by the plateletderived growth factor is mediated via multiple signaling pathways. J Biol Chem. 1999;274(15):10489-96. https://doi.org/10. 1074/jbc.274.15.10489.

30. Leithe E, Rivedal E. Epidermal growth factor regulates ubiquitination, internalization and proteasome-dependent degradation of connexin43. J Cell Sci. 2004;117(Pt 7):1211-20. https:// doi.org/10.1242/jcs.00951.

31. Cooper CD, Lampe PD. Casein kinase 1 regulates connexin- 43 gap junction assembly. J Biol Chem. 2002;277(47):44962-8. https://doi.org/10.1074/jbc.M209427200.

32. Atkinson MM, Lampe PD, Lin HH, Kollander R, Li XR, Kiang DT. Cyclic AMP modifies the cellular distribution of connexin 43 and induces a persistent increase in the junctional permeability of mouse mammary tumor cells. J Cell Sci. 1995;108(Pt 9):3079-90.

33. Paulson AF, Lampe PD, Meyer RA, TenBroek E, Atkinson MM, Walseth TF, et al. Cyclic AMP and LDL trigger a rapid 
enhancement in gap junction assembly through a stimulation of connexin trafficking. J Cell Sci. 2000;113(Pt 17):3037-49.

34. Shah MM, Martinez AM, Fletcher WH. The connexin43 gap junction protein is phosphorylated by protein kinase $\mathrm{A}$ and protein kinase $\mathrm{C}$ : in vivo and in vitro studies. Mol Cell Biochem. 2002;238(1-2):57-68. https://doi.org/10.1023/A: 1019902920693.

35. Mesnil M, Krutovskikh V, Piccoli C, Elfgang C, Traub O, Willecke K, et al. Negative growth control of HeLa cells by connexin genes: connexin species specificity. Cancer Res. 1995;55(3):629-39.

36. Moorby C, Patel M. Dual functions for connexins: $\mathrm{Cx} 43$ regulates growth independently of gap junction formation. Exp Cell Res. 2001;271(2):238-48. https://doi.org/10.1006/excr.2001.5357.

37. Qin H, Shao Q, Curtis H, Galipeau J, Belliveau DJ, Wang T, et al. Retroviral delivery of connexin genes to human breast tumor cells inhibits in vivo tumor growth by a mechanism that is independent of significant gap junctional intercellular communication. J Biol Chem. 2002;277(32):29132-8. https://doi.org/10.1074/jbc. M200797200.

38. Yamasaki H, Krutovskikh V, Mesnil M, Tanaka T, Zaidan-Dagli ML, Omori Y. Role of connexin (gap junction) genes in cell growth control and carcinogenesis. C R Acad Sci III. 1999;322(2-3):151-9. https://doi.org/10.1016/S0764-4469(99) 80038-9.

39. Huang RP, Fan Y, Hossain MZ, Peng A, Zeng ZL, Boynton AL. Reversion of the neoplastic phenotype of human glioblastoma cells by connexin 43 (cx43). Cancer Res. 1998;58(22):5089-96.

40. Dang X, Doble BW, Kardami E. The carboxy-tail of connexin-43 localizes to the nucleus and inhibits cell growth. Mol Cell Biochem. 2003;242(1-2):35-8. https://doi.org/10.1023/A: 1021152709313.

41. Zhang YW, Kaneda M, Morita I. The gap junction-independent tumor-suppressing effect of connexin 43. J Biol Chem. 2003;278(45):44852-6. https://doi.org/10.1074/jbc. M305072200.

42. Kardami E, Dang X, Iacobas DA, Nickel BE, Jeyaraman M, Srisakuldee W, et al. The role of connexins in controlling cell growth and gene expression. Prog Biophys Mol Biol. 2007;94(1-2):245-64. https://doi.org/10.1016/j.pbiomolbio. 2007.03.009.

43.• Maqbool R, Rashid R, Ismail R, Niaz S, Chowdri NA, Hussain MU. The carboxy-terminal domain of connexin 43 (CT-Cx43) modulates the expression of $\mathrm{p} 53$ by altering miR-125b expression in low-grade human breast cancers. Cell Oncol (Dordr). 2015;38(6):443-51. This study demonstrates that the cytosplasmic terminal domain of $\mathrm{Cx} 43$ specifically upregulates p53 expression and decreases MCF-7 cells proliferation. https://doi.org/10.1007/s13402-015-0240-x.

44. Talhouk RS, Fares MB, Rahme GJ, Hariri HH, Rayess T, Dbouk HA, et al. Context dependent reversion of tumor phenotype by connexin-43 expression in MDA-MB231 cells and MCF-7 cells: role of beta-catenin/connexin43 association. Exp Cell Res. 2013;319(20):3065-80. https://doi.org/10.1016/j.yexcr.2013.10. 002 .

45. MacDonald BT, Tamai K, He X. Wnt/beta-catenin signaling: components, mechanisms, and diseases. Dev Cell. 2009;17(1):9-26. https://doi.org/10.1016/j.devcel.2009.06.016.

46. Giepmans BN. Gap junctions and connexin-interacting proteins. Cardiovasc Res. 2004;62(2):233-45. https://doi.org/10.1016/j. cardiores.2003.12.009.

47. Maass K, Shibayama J, Chase SE, Willecke K, Delmar M. Cterminal truncation of connexin 43 changes number, size, and localization of cardiac gap junction plaques. Circ Res. 2007;101(12):1283-91. https://doi.org/10.1161/CIRCRESAHA. 107.162818 .
48. Cina C, Maass K, Theis M, Willecke K, Bechberger JF, Naus CC. Involvement of the cytoplasmic $\mathrm{C}$-terminal domain of connexin 43 in neuronal migration. J Neurosci. 2009;29(7):2009-21. https:// doi.org/10.1523/JNEUROSCI.5025-08.2009.

49. Kozoriz MG, Bechberger JF, Bechberger GR, Suen MW, Moreno $\mathrm{AP}$, Maass $\mathrm{K}$, et al. The connexin43 C-terminal region mediates neuroprotection during stroke. J Neuropathol Exp Neurol. 2010;69(2):196-206. https://doi.org/10.1097/NEN. 0b013e3181cd44df.

50.• Moorer MC, Hebert C, Tomlinson RE, Iyer SR, Chason M, Stains JP. Defective signaling, osteoblastogenesis and bone remodeling in a mouse model of connexin $43 \mathrm{C}$-terminal truncation. J Cell Sci. 2017;130(3):531-40. This study provides evidence that Connexin 43 cytoplasmic tail binds PKC $\delta$, ERK1, ERK2 and $\beta$-catenin, hence functioning as a docking platform for signaling effectors that maintain optimal osteoblast function. https://doi.org/10.1242/jcs.197285.

51. Gago-Fuentes R, Bechberger JF, Varela-Eirin M, Varela-Vazquez A, Acea B, Fonseca E, et al. The C-terminal domain of connexin 43 modulates cartilage structure via chondrocyte phenotypic changes. Oncotarget. 2016;7(45):73055-67. https://doi.org/ 10.18632/oncotarget.12197.

52. Schofield R. The relationship between the spleen colony-forming cell and the haemopoietic stem cell. Blood Cells. 1978;4(1-2):725. The authors highligted the importance of Connexin 43 cytoplasmic tail is required for maintaining cartilage structure and normal chondrocyte phenotype. For their study they used the $\mathrm{Cx} 43$ cytoplasmic tail deficient mice: $\mathrm{K258stop} / \mathrm{Cx} 43 \mathrm{KO}$ and K258stop/K258stop.

53. Xie Y, Yin T, Wiegraebe W, He XC, Miller D, Stark D, et al. Detection of functional haematopoietic stem cell niche using real-time imaging. Nature. 2009;457(7225):97-101. https://doi. org/10.1038/nature07639.

54. Ramasamy SK, Kusumbe AP, Adams RH. Regulation of tissue morphogenesis by endothelial cell-derived signals. Trends Cell Biol. 2015;25(3):148-57. https://doi.org/10.1016/j.tcb.2014.11. 007.

55. Calvi LM, Adams GB, Weibrecht KW, Weber JM, Olson DP, Knight MC, et al. Osteoblastic cells regulate the haematopoietic stem cell niche. Nature. 2003;425(6960):841-6. https://doi.org/ 10.1038/nature 02040.

56. Li L, Clevers H. Coexistence of quiescent and active adult stem cells in mammals. Science. 2010;327(5965):542-5. https://doi. org/10.1126/science. 1180794.

57. Sugimura R, He XC, Venkatraman A, Arai F, Box A, Semerad C, et al. Noncanonical Wnt signaling maintains hematopoietic stem cells in the niche. Cell. 2012;150(2):351-65. https://doi.org/10. 1016/j.cell.2012.05.041.

58. Ding L, Morrison SJ. Haematopoietic stem cells and early lymphoid progenitors occupy distinct bone marrow niches. Nature. 2013;495(7440):231-5. https://doi.org/10.1038/nature11885.

59. Ding L, Saunders TL, Enikolopov G, Morrison SJ. Endothelial and perivascular cells maintain haematopoietic stem cells. Nature. 2012;481(7382):457-62. https://doi.org/10.1038/nature10783.

60. Kiel MJ, Morrison SJ. Uncertainty in the niches that maintain haematopoietic stem cells. Nat Rev Immunol. 2008;8(4):290 301. https://doi.org/10.1038/nri2279.

61. Kiel MJ, Yilmaz OH, Iwashita T, Yilmaz OH, Terhorst C, Morrison SJ. SLAM family receptors distinguish hematopoietic stem and progenitor cells and reveal endothelial niches for stem cells. Cell. 2005;121(7):1109-21. https://doi.org/10.1016/j.cell. 2005.05.026.

62. Kiel MJ, Radice GL, Morrison SJ. Lack of evidence that hematopoietic stem cells depend on N-cadherin-mediated adhesion to osteoblasts for their maintenance. Cell Stem Cell. 2007;1(2): 204-17. https://doi.org/10.1016/j.stem.2007.06.001. 
63. Sacchetti B, Funari A, Michienzi S, Di Cesare S, Piersanti S, Saggio I, et al. Self-renewing osteoprogenitors in bone marrow sinusoids can organize a hematopoietic microenvironment. Cell. 2007;131(2):324-36. https://doi.org/10.1016/j.cell.2007.08.025.

64. Kopp HG, Avecilla ST, Hooper AT, Rafii S. The bone marrow vascular niche: home of HSC differentiation and mobilization. Physiology (Bethesda). 2005;20:349-56. https://doi.org/10.1152/ physiol.00025.2005.

65. Kunisaki Y, Bruns I, Scheiermann C, Ahmed J, Pinho S, Zhang D, et al. Arteriolar niches maintain haematopoietic stem cell quiescence. Nature. 2013;502(7473):637-43. https://doi.org/10.1038/ nature12612.

66. Wilson A, Murphy MJ, Oskarsson T, Kaloulis K, Bettess MD, Oser GM, et al. c-Myc controls the balance between hematopoietic stem cell self-renewal and differentiation. Genes Dev. 2004;18(22):2747-63. https://doi.org/10.1101/gad.313104.

67. Wilson A, Trumpp A. Bone-marrow haematopoietic-stem-cell niches. Nat Rev Immunol. 2006;6(2):93-106. https://doi.org/10. 1038/nri1779.

68. Zhang J, Niu C, Ye L, Huang H, He X, Tong WG, et al. Identification of the haematopoietic stem cell niche and control of the niche size. Nature. 2003;425(6960):836-41. https://doi.org/ 10.1038/nature 02041 .

69. Fleming I. Double tribble: two TRIB3 variants, insulin, Akt, and eNOS. Arterioscler Thromb Vasc Biol. 2008;28(7):1216-8. https://doi.org/10.1161/ATVBAHA.108.169250.

70. Malhotra S, Kincade PW. Wnt-related molecules and signaling pathway equilibrium in hematopoiesis. Cell Stem Cell. 2009;4(1):27-36. https://doi.org/10.1016/j.stem.2008.12.004.

71. Reya T, Duncan AW, Ailles L, Domen J, Scherer DC, Willert K, et al. A role for Wnt signalling in self-renewal of haematopoietic stem cells. Nature. 2003;423(6938):409-14. https://doi.org/10. 1038/nature01593.

72. Willert K, Brown JD, Danenberg E, Duncan AW, Weissman IL, Reya T, et al. Wnt proteins are lipid-modified and can act as stem cell growth factors. Nature. 2003;423(6938):448-52. https://doi. org/10.1038/nature01611.

73. Domen J, Weissman IL. Self-renewal, differentiation or death: regulation and manipulation of hematopoietic stem cell fate. Mol Med Today. 1999;5(5):201-8. https://doi.org/10.1016/S13574310(99)01464-1.

74. Suzuki T, Yokoyama Y, Kumano K, Takanashi M, Kozuma S, Takato T, et al. Highly efficient ex vivo expansion of human hematopoietic stem cells using Delta1-Fc chimeric protein. Stem Cells. 2006;24(11):2456-65. https://doi.org/10.1634/stemcells. 2006-0258.

75. Varnum-Finney B, Purton LE, Yu M, Brashem-Stein C, Flowers $\mathrm{D}$, Staats S, et al. The Notch ligand, Jagged-1, influences the development of primitive hematopoietic precursor cells. Blood. 1998;91(11):4084-91.

76. Civitelli R, Beyer EC, Warlow PM, Robertson AJ, Geist ST, Steinberg TH. Connexin43 mediates direct intercellular communication in human osteoblastic cell networks. J Clin Invest. 1993;91(5):1888-96. https://doi.org/10.1172/JCI116406.

77. Durig J, Rosenthal C, Halfmeyer K, Wiemann M, Novotny J, Bingmann D, et al. Intercellular communication between bone marrow stromal cells and CD34+ haematopoietic progenitor cells is mediated by connexin 43-type gap junctions. Br J Haematol. 2000;111(2):416-25. https://doi.org/10.1046/j.1365-2141.2000. 02385.x.

78. Harris AL. Connexin channel permeability to cytoplasmic molecules. Prog Biophys Mol Biol. 2007;94(1-2):120-43. https://doi. org/10.1016/j.pbiomolbio.2007.03.011.

79. Campbell FR. Gap junctions between cells of bone marrow: an ultrastructural study using tannic acid. Anat Rec. 1980;196(1): 101-7. https://doi.org/10.1002/ar.1091960110.
80. Gonzalez-Nieto D, Chang KH, Fasciani I, Nayak R, FernandezGarcia L, Barrio LC, et al. Connexins: intercellular signal transmitters in lymphohematopoietic tissues. Int Rev Cell Mol Biol. 2015;318:27-62. https://doi.org/10.1016/bs.ircmb.2015.06.001.

81. Wagner W, Wein F, Roderburg C, Saffrich R, Diehlmann A, Eckstein $\mathrm{V}$, et al. Adhesion of human hematopoietic progenitor cells to mesenchymal stromal cells involves CD44. Cells Tissues Organs. 2008;188(1-2):160-9. https://doi.org/10.1159/ 000112821.

82. Bodi E, Hurtado SP, Carvalho MA, Borojevic R, Carvalho AC. Gap junctions in hematopoietic stroma control proliferation and differentiation of blood cell precursors. An Acad Bras Cienc. 2004;76(4):743-56. https://doi.org/10.1590/S000137652004000400009 .

83. Himburg HA, Harris JR, Ito T, Daher P, Russell JL, Quarmyne M, et al. Pleiotrophin regulates the retention and self-renewal of hematopoietic stem cells in the bone marrow vascular niche. Cell Rep. 2012;2(4):964-75. https://doi.org/10.1016/j.celrep.2012.09. 002.

84. Poulos MG, Guo P, Kofler NM, Pinho S, Gutkin MC, Tikhonova A, et al. Endothelial Jagged-1 is necessary for homeostatic and regenerative hematopoiesis. Cell Rep. 2013;4(5):1022-34. https://doi.org/10.1016/j.celrep.2013.07.048.

85. Winkler IG, Barbier V, Nowlan B, Jacobsen RN, Forristal CE, Patton JT, et al. Vascular niche E-selectin regulates hematopoietic stem cell dormancy, self renewal and chemoresistance. Nat Med. 2012;18(11):1651-7. https://doi.org/10.1038/nm.2969.

86. Reaume AG, de Sousa PA, Kulkarni S, Langille BL, Zhu D, Davies TC, et al. Cardiac malformation in neonatal mice lacking connexin43. Science. 1995;267(5205):1831-4. https://doi.org/10. 1126/science.7892609.

87. Cancelas JA, Koevoet WL, de Koning AE, Mayen AE, Rombouts EJ, Ploemacher RE. Connexin-43 gap junctions are involved in multiconnexin-expressing stromal support of hemopoietic progenitors and stem cells. Blood. 2000;96(2):498-505.

88. Paraguassu-Braga FH, Alves AP, Santos IM, Bonamino M, Bonomo A. An ectopic stromal implant model for hematopoietic reconstitution and in vivo evaluation of bone marrow niches. Cell Transplant. 2012;21(12):2677-88. https://doi.org/10.3727/ 096368912 X636993.

89. Presley CA, Lee AW, Kastl B, Igbinosa I, Yamada Y, Fishman GI, et al. Bone marrow connexin-43 expression is critical for hematopoietic regeneration after chemotherapy. Cell Commun Adhes. $2005 ; 12(5-6): 307-17$. https://doi.org/10.1080/ 15419060500514200 .

90. Genet N, Billaud M, Rossignol R, Dubois M, Gillibert-Duplantier $\mathrm{J}$, Isakson BE, et al. Signaling pathways linked to serotonininduced superoxide anion production: a physiological role for mitochondria in pulmonary arteries. Front Physiol. 2017;8:76.

91. Ishikawa ET, Cancelas JA. Lack of communication rusts and ages stem cells. Cell Cycle. 2012;11(17):3149-50. https://doi.org/10. 4161/cc. 21589.

92. Taniguchi Ishikawa E, Gonzalez-Nieto D, Ghiaur G, Dunn SK, Ficker AM, Murali B, et al. Connexin-43 prevents hematopoietic stem cell senescence through transfer of reactive oxygen species to bone marrow stromal cells. Proc Natl Acad Sci U S A. 2012;109(23):9071-6. https://doi.org/10.1073/pnas.1120358109.

93. Doetsch F, Caille I, Lim DA, Garcia-Verdugo JM, Alvarez-Buylla A. Subventricular zone astrocytes are neural stem cells in the adult mammalian brain. Cell. 1999;97(6):703-16. https://doi.org/10. 1016/S0092-8674(00)80783-7.

94. Kazanis I, Lathia JD, Vadakkan TJ, Raborn E, Wan R, Mughal $\mathrm{MR}$, et al. Quiescence and activation of stem and precursor cell populations in the subependymal zone of the mammalian brain are associated with distinct cellular and extracellular matrix signals. J 
Neurosci. 2010;30(29):9771-81. https://doi.org/10.1523/ JNEUROSCI.0700-10.2010.

95. Shen Q, Wang Y, Kokovay E, Lin G, Chuang SM, Goderie SK, et al. Adult SVZ stem cells lie in a vascular niche: a quantitative analysis of niche cell-cell interactions. Cell Stem Cell. 2008;3(3): 289-300. https://doi.org/10.1016/j.stem.2008.07.026.

96. Mirzadeh Z, Merkle FT, Soriano-Navarro M, Garcia-Verdugo JM, Alvarez-Buylla A. Neural stem cells confer unique pinwheel architecture to the ventricular surface in neurogenic regions of the adult brain. Cell Stem Cell. 2008;3(3):265-78. https://doi.org/10. 1016/j.stem.2008.07.004.

97. Tavazoie M, Van der Veken L, Silva-Vargas V, Louissaint M, Colonna L, Zaidi B, et al. A specialized vascular niche for adult neural stem cells. Cell Stem Cell. 2008;3(3):279-88. https://doi. org/10.1016/j.stem.2008.07.025.

98. Doetsch F, Garcia-Verdugo JM, Alvarez-Buylla A. Cellular composition and three-dimensional organization of the subventricular germinal zone in the adult mammalian brain. J Neurosci. 1997;17(13):5046-61.

99. Garcia-Verdugo JM, Doetsch F, Wichterle H, Lim DA, AlvarezBuylla A. Architecture and cell types of the adult subventricular zone: in search of the stem cells. J Neurobiol. 1998;36(2):234 48. https://doi.org/10.1002/(SICI)1097-4695(199808)36:2<234:: AID-NEU10>3.0.CO;2-E.

100. Altman J. Autoradiographic and histological studies of postnatal neurogenesis. IV. Cell proliferation and migration in the anterior forebrain, with special reference to persisting neurogenesis in the olfactory bulb. J Comp Neurol. 1969;137(4):433-57. https://doi. org/10.1002/cne.901370404.

101. Alvarez-Buylla A, Garcia-Verdugo JM. Neurogenesis in adult subventricular zone. J Neurosci. 2002;22(3):629-34.

102. Encinas JM, Enikolopov G. Identifying and quantitating neural stem and progenitor cells in the adult brain. Methods Cell Biol. 2008;85:243-72. https://doi.org/10.1016/S0091-679X(08)85011$\mathrm{X}$.

103. Temple S. The development of neural stem cells. Nature. 2001;414(6859):112-7. https://doi.org/10.1038/35102174.

104. Shen Q, Goderie SK, Jin L, Karanth N, Sun Y, Abramova N, et al. Endothelial cells stimulate self-renewal and expand neurogenesis of neural stem cells. Science. 2004;304(5675):1338-40. https:// doi.org/10.1126/science.1095505.

105. Ramirez-Castillejo C, Sanchez-Sanchez F, Andreu-Agullo C, Ferron SR, Aroca-Aguilar JD, Sanchez P, et al. Pigment epithelium-derived factor is a niche signal for neural stem cell renewal. Nat Neurosci. 2006;9(3):331-9. https://doi.org/10. 1038/nn1657.

106. Gomez-Gaviro MV, Lovell-Badge R, Fernandez-Aviles F, LaraPezzi E. The vascular stem cell niche. J Cardiovasc Transl Res. 2012;5(5):618-30. https://doi.org/10.1007/s12265-012-9371-x.

107. Doetsch F. A niche for adult neural stem cells. Curr Opin Genet Dev. 2003;13(5):543-50. https://doi.org/10.1016/j.gde.2003.08. 012 .

108. Crouch EE, Liu C, Silva-Vargas V, Doetsch F. Regional and stagespecific effects of prospectively purified vascular cells on the adult V-SVZ neural stem cell lineage. J Neurosci. 2015;35(11):452839. https://doi.org/10.1523/JNEUROSCI.1188-14.2015.

109. Kokovay E, Goderie S, Wang Y, Lotz S, Lin G, Sun Y, et al. Adult SVZ lineage cells home to and leave the vascular niche via differential responses to SDF1/CXCR4 signaling. Cell Stem Cell. 2010;7(2):163-73. https://doi.org/10.1016/j.stem.2010.05.019.

110. Ottone C, Krusche B, Whitby A, Clements M, Quadrato G, Pitulescu ME, et al. Direct cell-cell contact with the vascular niche maintains quiescent neural stem cells. Nat Cell Biol. 2014;16(11): 1045-56. This study demonstrates in an elegant manner that direct contact contact between vascular endothelial cells and neural stem cells via ephrin-B2 and jagged-1 maintains neural stem cells quiescence in the adult brain subventricular zone. https://doi.org/10.1038/ncb3045.

111. Ottone C, Parrinello S. Multifaceted control of adult SVZ neurogenesis by the vascular niche. Cell Cycle. 2015;14(14): 2222-5. https://doi.org/10.1080/15384101.2015.1049785.

112. Cheng A, Tang H, Cai J, Zhu M, Zhang X, Rao M, et al. Gap junctional communication is required to maintain mouse cortical neural progenitor cells in a proliferative state. Dev Biol. 2004;272(1):203-16. https://doi.org/10.1016/j.ydbio.2004.04. 031.

113. Todorova MG, Soria B, Quesada I. Gap junctional intercellular communication is required to maintain embryonic stem cells in a non-differentiated and proliferative state. J Cell Physiol. 2008;214(2):354-62. https://doi.org/10.1002/jcp.21203.

114. Elias LA, Turmaine M, Parnavelas JG, Kriegstein AR. Connexin 43 mediates the tangential to radial migratory switch in ventrally derived cortical interneurons. J Neurosci. 2010;30(20):7072-7. https://doi.org/10.1523/JNEUROSCI.5728-09.2010.

115. Elias LA, Wang DD, Kriegstein AR. Gap junction adhesion is necessary for radial migration in the neocortex. Nature. 2007;448(7156):901-7. https://doi.org/10.1038/nature06063.

116. Wiencken-Barger AE, Djukic B, Casper KB, McCarthy KD. A role for Connexin43 during neurodevelopment. Glia. 2007;55(7): 675-86. https://doi.org/10.1002/glia.20484.

117. Malmersjo S, Rebellato P, Smedler E, Uhlen P. Small-world networks of spontaneous $\mathrm{ca}(2+)$ activity. Commun Integr Biol. 2013;6(4):e24788. https://doi.org/10.4161/cib.24788.

118. Lacar B, Young SZ, Platel JC, Bordey A. Gap junction-mediated calcium waves define communication networks among murine postnatal neural progenitor cells. Eur J Neurosci. 2011;34(12): 1895-905. https://doi.org/10.1111/j.1460-9568.2011.07901.x.

119. Lacar B, Herman P, Hartman NW, Hyder F, Bordey A. S phase entry of neural progenitor cells correlates with increased blood flow in the young subventricular zone. PLoS One. 2012;7(2): e31960. https://doi.org/10.1371/journal.pone.0031960.

120. Lacar B, Herman P, Platel JC, Kubera C, Hyder F, Bordey A. Neural progenitor cells regulate capillary blood flow in the postnatal subventricular zone. J Neurosci. 2012;32(46):16435-48. https://doi.org/10.1523/JNEUROSCI.1457-12.2012.

121. Seri B, Garcia-Verdugo JM, Collado-Morente L, McEwen BS, Alvarez-Buylla A. Cell types, lineage, and architecture of the germinal zone in the adult dentate gyrus. J Comp Neurol. 2004;478(4):359-78. https://doi.org/10.1002/cne.20288.

122. Goncalves JT, Schafer ST, Gage FH. Adult neurogenesis in the hippocampus: from stem cells to behavior. Cell. 2016;167(4):897914. https://doi.org/10.1016/j.cell.2016.10.021.

123. Walton RM. Postnatal neurogenesis: of mice, men, and macaques. Vet Pathol. 2012;49(1):155-65. https://doi.org/10.1177/ 0300985811414035.

124. Palmer TD, Willhoite AR, Gage FH. Vascular niche for adult hippocampal neurogenesis. J Comp Neurol. 2000;425(4):479 94. https://doi.org/10.1002/1096-9861(20001002)425:4<479:: AID-CNE2>3.0.CO;2-3.

125. Han J, Calvo CF, Kang TH, Baker KL, Park JH, Parras C, et al. Vascular endothelial growth factor receptor 3 controls neural stem cell activation in mice and humans. Cell Rep. 2015;10(7):115872. This is the first study underlying the role of VEGFR3 and its ligand VEGF-C in the regulation of adult hippocampal neurogenesis. https://doi.org/10.1016/j.celrep.2015.01.049.

126. Rozental R, Mehler MF, Morales M, Andrade-Rozental AF, Kessler JA, Spray DC. Differentiation of hippocampal progenitor cells in vitro: temporal expression of intercellular coupling and voltage- and ligand-gated responses. Dev Biol. 1995;167(1): 350-62. https://doi.org/10.1006/dbio.1995.1029.

127. Rozental R, Morales M, Mehler MF, Urban M, Kremer M, Dermietzel R, et al. Changes in the properties of gap junctions 
during neuronal differentiation of hippocampal progenitor cells. $\mathrm{J}$ Neurosci. 1998;18(5):1753-62.

128. Kunze A, Congreso MR, Hartmann C, Wallraff-Beck A, Huttmann K, Bedner $\mathrm{P}$, et al. Connexin expression by radial glia-like cells is required for neurogenesis in the adult dentate gyrus. Proc Natl Acad Sci U S A. 2009;106(27):11336-41. https://doi.org/10.1073/pnas.0813160106.

129. Liebmann M, Stahr A, Guenther M, Witte OW, Frahm C. Astrocytic Cx43 and Cx30 differentially modulate adult neurogenesis in mice. Neurosci Lett. 2013;545:40-5. https://doi. org/10.1016/j.neulet.2013.04.013.

130.• Greer K, Chen J, Brickler T, Gourdie R, Theus MH. Modulation of gap junction-associated $\mathrm{Cx} 43$ in neural stem/progenitor cells following traumatic brain injury. Brain Res Bull. 2017;134:38-46. This recent study demonstrates that the expression of connexin 43 is upregulated un the dentate gyrus following traumatic brain injury. https://doi.org/10.1016/j.brainresbull. 2017.06.016.

131.• Shin J, Berg DA, Zhu Y, Shin JY, Song J, Bonaguidi MA, et al. Single-cell RNA-Seq with waterfall reveals molecular cascades underlying adult neurogenesis. Cell Stem Cell. 2015;17(3):360 72. This unique state-of-the-art study performed single-cell RNA sequencing analysis in the dentate gyrus of the mouse hippocampus and showed that the expression of connexin 43 is downregulated in activated neural stem cells and proliferating neural progenitor cells. https://doi.org/10.1016/j.stem.2015.07. 013.

132. Hsu YC, Li L, Fuchs E. Emerging interactions between skin stem cells and their niches. Nat Med. 2014;20(8):847-56. https://doi. org/10.1038/nm.3643.

133. Blanpain C, Fuchs E. Epidermal homeostasis: a balancing act of stem cells in the skin. Nat Rev Mol Cell Biol. 2009;10(3):207-17. https://doi.org/10.1038/nrm2636.

134. Sennett R, Rendl M. Mesenchymal-epithelial interactions during hair follicle morphogenesis and cycling. Semin Cell Dev Biol. 2012;23(8):917-27. https://doi.org/10.1016/j.semcdb.2012.08. 011 .

135. Greco V, Chen T, Rendl M, Schober M, Pasolli HA, Stokes N, et al. A two-step mechanism for stem cell activation during hair regeneration. Cell Stem Cell. 2009;4(2):155-69. https://doi.org/ 10.1016/j.stem.2008.12.009.

136. Lien WH, Polak L, Lin M, Lay K, Zheng D, Fuchs E. In vivo transcriptional governance of hair follicle stem cells by canonical Wnt regulators. Nat Cell Biol. 2014;16(2):179-90. https://oi.org/ 10.1038/ncb2903.

137. Mecklenburg L, Tobin DJ, Muller-Rover S, Handjiski B, Wendt $\mathrm{G}$, Peters EM, et al. Active hair growth (anagen) is associated with angiogenesis. J Invest Dermatol. 2000;114(5):909-16. https://doi. org/10.1046/j.1523-1747.2000.00954.x.

138. Zhang XF, Cui X. Connexin 43: key roles in the skin. Biomed Rep. 2017;6(6):605-11. https://doi.org/10.3892/br.2017.903.

139. Dyce PW, Li D, Barr KJ, Kidder GM. Connexin 43 is required for the maintenance of multipotency in skin-derived stem cells. Stem Cells Dev. 2014;23(14):1636-46. https://doi.org/10.1089/scd. 2013.0459.
140. Young P, Boussadia O, Halfter H, Grose R, Berger P, Leone DP, et al. E-cadherin controls adherens junctions in the epidermis and the renewal of hair follicles. EMBO J. 2003;22(21):5723-33. https://doi.org/10.1093/emboj/cdg560.

141. Yano T, Yamasaki H. Regulation of cellular invasion and matrix metalloproteinase activity in HepG2 cell by connexin 26 transfection. Mol Carcinog. 2001;31(2):101-9. https://doi.org/10.1002/ mc.1045.

142. Jongen WM, Fitzgerald DJ, Asamoto M, Piccoli C, Slaga TJ, Gros $\mathrm{D}$, et al. Regulation of connexin 43-mediated gap junctional intercellular communication by $\mathrm{Ca} 2+$ in mouse epidermal cells is controlled by E-cadherin. J Cell Biol. 1991;114(3):545-55. https:// doi.org/10.1083/jcb.114.3.545.

143. Kretz M, Euwens C, Hombach S, Eckardt D, Teubner B, Traub O, et al. Altered connexin expression and wound healing in the epidermis of connexin-deficient mice. J Cell Sci. 2003;116(Pt 16): 3443-52. https://doi.org/10.1242/jcs.00638.

144. Plante I, Stewart MK, Barr K, Allan AL, Laird DW. Cx43 suppresses mammary tumor metastasis to the lung in a $\mathrm{Cx} 43$ mutant mouse model of human disease. Oncogene. 2011;30(14):168192. https://doi.org/10.1038/onc.2010.551.

145. Cogliati B, Vinken M, Silva TC, Araujo CMM, Aloia TPA, Chaible LM, et al. Connexin 43 deficiency accelerates skin wound healing and extracellular matrix remodeling in mice. J Dermatol Sci. 2015;79(1):50-6. https://doi.org/10.1016/j.jdermsci.2015.03. 019.

146. Qiu C, Coutinho P, Frank S, Franke S, Law LY, Martin P, et al. Targeting connexin43 expression accelerates the rate of wound repair. Curr Biol. 2003;13(19):1697-703. https://doi.org/10. 1016/j.cub.2003.09.007.

147. Mori R, Power KT, Wang CM, Martin P, Becker DL. Acute downregulation of connexin 43 at wound sites leads to a reduced inflammatory response, enhanced keratinocyte proliferation and wound fibroblast migration. J Cell Sci. 2006;119(Pt 24):5193-203. https://doi.org/10.1242/jcs.03320.

148. Wang CM, Lincoln J, Cook JE, Becker DL. Abnormal connexin expression underlies delayed wound healing in diabetic skin. Diabetes. 2007;56(11):2809-17. https://doi.org/10.2337/db070613.

149. Hunter AW, Barker RJ, Zhu C, Gourdie RG. Zonula occludens-1 alters connexin 43 gap junction size and organization by influencing channel accretion. Mol Biol Cell. 2005;16(12):5686-98. https://doi.org/10.1091/mbc.E05-08-0737.

150. Ghatnekar GS, O'Quinn MP, Jourdan LJ, Gurjarpadhye AA, Draughn RL, Gourdie RG. Connexin43 carboxyl-terminal peptides reduce scar progenitor and promote regenerative healing following skin wounding. Regen Med. 2009;4(2):205-23. https://doi.org/10.2217/17460751.4.2.205.

151. Mendoza-Naranjo A, Cormie P, Serrano AE, Wang CM, Thrasivoulou C, Sutcliffe JE, et al. Overexpression of the gap junction protein $\mathrm{Cx} 43$ as found in diabetic foot ulcers can retard fibroblast migration. Cell Biol Int. 2012;36(7):661-7. https://doi. org/10.1042/CBI20110628. 